Stackelberg4), Kolthoff-Linganes) らの成書に記載が あり，分析目的に適しない旨報告されている. しかし著 者は次の点を考虑して $\mathrm{Ph}_{4} \mathrm{P}^{+}+\mathrm{MnO}_{4}^{-} \rightarrow \mathrm{Ph}_{4} \mathrm{P} \cdot \mathrm{MnO}_{4}$ の電流滴定を試みた.

i ）溶存酸素の過マンガン酸に対する影響

ii ）水銀の還元作用による供試溶液の変化

iii）支持電解質イオンの過マンガン酸根に対する影響

iv）供試溶液の $\mathrm{pH}$

上記の点を検討して得た過マンガン酸根のポーラログ ラム (Fig. 1 曲線 d) では 0V において既に還元を始 め $-1.65 \mathrm{~V}$ に第 2 波を示す限定的 2 段波を得た。第 1 波は $\mathrm{Mn}^{\mathrm{VII}} \rightarrow \mathrm{Mn}$ II, 第 2 波は $\mathrm{Mn}^{\mathrm{II}} \rightarrow \mathrm{Mn}^{0}$ と考光られ る.

次に電流滴定曲線について検討する. 過マンガン酸錯 陰イオンは TPP 陽イオン $\left(\mathrm{C}_{6} \mathrm{H}_{5}\right)_{4} \mathrm{P}^{+}$と沈殿反応を行 ない結晶性赤紫色沈殿を形成する，すなわち，滴定曲 線の終点においては, 使用した溶液の濃度および 容積 から計算すると $\mathrm{MnO}_{4}^{-}:\left(\mathrm{C}_{6} \mathrm{H}_{5}\right)_{4} \mathrm{P}^{+}=1: 1$ となり, $\left(\mathrm{C}_{6} \mathrm{H}_{5}\right)_{4} \mathrm{PMnO}_{4}$ なる沈殿組成に相当する. 滴定誤差は $\pm 2 \%$ となる.

\section{$4 \cdot 2$ T. P. P. C. による過塩秦酸根の電流滴定}

過塩素酸根はポーラログラフ的に還元波を示さないこ とが知られており，この滴定に当っては TPP 陽イオン 還元波に伴う極大波を支持電解質(塭化カリウム)濃度調 整により抑制した上この還元波の増減を測定した（Fig. 6). この際沈殿生成時間は過マンガン酸根の時に比べて 大となるので沈殿熟成時間を調べ試薬添加後 15 分放置 して電流值を測定した. 過塩素酸根と T.P.P. 陽イオ ンの沈殿反応により得られた白色沈殿は, 滴定終点に おいて使用した 溶液の濃度および容積から 計算すると $\mathrm{ClO}_{4}^{-}:\left(\mathrm{C}_{6} \mathrm{H}_{5}\right)_{4} \mathrm{P}^{+}=1: 1$ となり, $\left(\mathrm{C}_{6} \mathrm{H}_{5}\right)_{4} \mathrm{ClO}_{4}$ なる 沈殿組成に相当すると考えられる. この際の滴定誤差は
土2\% である.なお，本法の実用性を増すために逆滴定 の検討も行なったが，良好な結果が得られなかったの で, ホスホニウムより陽電位で還元するスルホニウムを 用い目下検討中である.

終りに本研究に種々御教示を賜わった品川睦明教授, 松尾博助教授に深䓕の感謝を表します.また本研究は 品川教授に対する文部省科学研究費によって行なった。 記して感謝します.

（昭和 29 年 4 月, 日本化学会第 7 年会講演）

$$
\text { 交献 }
$$

1）品川晆明，松尾 博，根津弘幸 : 本誌， 5, 20 (1956).

2) H. A. Potratz, J. M. Rosen : Anal. Chem., 21, 1276 (1949).

3) H. H. Willard, L. P. Perkins : ibid., 25, 1634 (1953).

4) M. von Stackelberg : "Polarographische Arbeitsmethoden", p. 146 (1950), (W. de Gruyter \& Co., Berlin).

5) I. M. Kolthoff, J. J. Lingane : "Polarography", 2nd Ed., Vol. II, p. 468 (1952), (Interscience Publishers Inc., New York).

6) I. M. Kolthoff, J. J. Lingane : ibid., 574. 放

Amperometric titrations of permanganate and perchlorate with tetraphenylphosphonium chloride. (Studies on the analytical application of onium compounds. XIX.) Hiroyuki NEZU (Dept. of Chem., Faculty of Science, Univ. of Hiroshima)

The investigation dealed with the application of tetraphenylphosphonium chloride as a quantitative reagent for permanganate and perchlorate by amperometric titration. The titration of permanganate $\left(10^{-3} \mathrm{~F}\right)$ in $0.5 \mathrm{~F}$ sodium sulfate could be carried out within an error of $\pm 2 \%$. In this case, $1 \mathrm{ml}$ of carbon tetrachloride was added to the cell, and it formed a layer on top of the mercury in the solution compartment of the cell, thus protecting the permanganate solution from the reducible metallic mercury. The titration of perchlorate $\left(10^{-3} \mathrm{~F}\right)$ in $2 \mathrm{~F}$ potassium chloride could be made within an error of $\pm 2 \%$. (Received Nov. 17, 1960)

\title{
テトラフェニルボロナトリウムによる 数程オニウム化合物の電流滴定*
}

\author{
根 津 弘 幸**
}

テトラフェニルボロナトリウムを試薬とし塩化ナトリウムを支持電解質として，対極に銀一塩化銀電 極を用い,トリフェニルスルホニウム・クロライド, トリフェニルセレノニウム・クロライド扰よびテ トラフェニルホスホニウム・クロライドの電流滴定を試み，いずれも $\pm 3 \%$ の滴定誤差内で滴定可能な ことを認めた. さらに沈殿の溶解度積を滴定曲線より概算し $10^{-8}$ 栴の值を得た.

*分析化学に颃けるオニウム化合物の適用に関する研究(第20報) **広島大学理学部化学教室 : 広島市東千田町 


\section{1 緒言}

オニウム化合物の分析法としては，第四級アンモニウ ム化合物が殺菌剂ならびに界面活性剂として広く実用に 供せられている現状に即して，第四級アンモニウム化合 物の各種分析法1が検討されてきた。

本研究はオニウム化合物の分析化学への適用に関する 一連の研究の一環として行なったものであり，アルカロ イド定量の基礎的研究として，その類縁化合物たる数種 カチオン系オニウム化合物の定量をアニオン系ボロニウ ム化合物2)を試薬として電流滴定を行なう上の検討をし たものである.

\section{2 実験および結果}

\section{$2 \cdot 1$ 試薬および装置}

2.1.1 試薬実験に用いた薬品はすべて試薬一級 品であった。

a ）テトラフェニルボロ・ナトリウム溶液：市販試薬 (片山化学) の濃度 $1.0 \times 10^{-2} M$ の水溶液を用い, 数日 経過した場合は新しく調整する.

b) オニウム水溶液：当教室で合成した 3 種のオニウ ム化合物を用いた。すなおち，

i ）トリフェニルスルホニウム・クロライド3) (T. P. Sul. C.), $1.0 \times 10^{-3} M$

ii）トリフェニルセレノニウム・クロライド4) (T.P. Se. C.), $1.0 \times 10^{-3} M$

iii) テトラフェニルホスホニウム・クロライド(T.P. P. C.), $1.0 \times 10^{-3} M$

Table I The configurations of the titrant added and the substances titrated

$$
\left[\begin{array}{c}
\mathrm{C}_{6} \mathrm{H}_{5} \\
\mathrm{C}_{6} \mathrm{H}_{5}-\mathrm{B}-\mathrm{C}_{6} \mathrm{H}_{5} \\
\mathrm{l}_{6} \mathrm{H}_{5}
\end{array}\right]^{-} \mathrm{Na}^{+}
$$

Sodium tetraphenylborate

$$
\left[\begin{array}{c}
\mathrm{C}_{6} \mathrm{H}_{5} \\
\mathrm{C}_{6} \mathrm{H}_{5}-\mathrm{P}-\mathrm{C}_{6} \mathrm{H}_{5} \\
\mathrm{C}_{6} \mathrm{H}_{5}
\end{array}\right]^{+} \mathrm{Cl}^{-}
$$

Tetraphenylphosphonium chloride

\section{$2 \cdot 1 \cdot 2$ 装羁}

a ） ポーラログラフは島津自記ポーラログラフ RP 1 型を用いた。

b ）銀一塩化銀電極：径 $0.5 \mathrm{~mm}$ の銀線を水銀滴下 極に合わせて螺旋状に巻いて整形したのち，ての銀線を $0.75 \mathrm{~N} \mathrm{HCl}$ 液溶中に插入して陽極とし, $5 \mathrm{~mA} / \mathrm{cm}^{2}$ の 電流密度で電解的塩化銀極とする．との電極電位は塩 化物溶液中で館和甘泉電極に対し $0.046 \mathrm{~V}$ だけ負電位で ある. 使用に際しては水銀滴下電極をこの螺旋状電極に 插入して固定する.

\section{$2 \cdot 2$ 実験結果}

支持電解質 $0.5 \mathrm{~F}$ 硫酸ナトリウムおよび $1 \mathrm{~F}$ 塩化ナト リウム, 基礎液 Britton-Robinson 䌅衝液 ( $\mathrm{pH} 2 \sim 12)$ について，それぞれ濃度 $10^{-3} M$ のテトラフェニルボロ. ナトリウム溶液がポーラログラムを与えるか否かを水銀 対極を用いて調べたところ，0〜 $-2.0 \mathrm{~V}$ の範囲におい てなんら特徴的な波を示さなかった. したがって電流滴 定を行なう場合にはオニウム・イオンの示す還元波の波 高の試薬添加による減少を見て滴定を行なった．対極と して飽和甘采電極を使用した場合は，寒天橋より塩化力 リウムが供試溶液中に拡散して滴定試薬と反応し沈殿を 生ずるので，以下の実験においては 銀-塩化銀電極を使 用して沈殿生成に伴う定量への障害を防止した. 実験值 はすべて飽和甘泉電極に対する値に換算した.

2.2.1 オニウム化合物のポーラログラム Fig. 1 のグラム a 祳度 $1.0 \times 10^{-3} M$ の T. P. Se. C. $(1 \mathrm{~F}$ 塩 化ナトリウム支持）溶液に窒素ガスを通じ溶存酸素を除 去したのち，銀一塩化銀電極を対極として得たポーラロ グラムを示す.これによると $-1.1 〜-1.2 \mathrm{~V}$ および $-1.3 \sim-1.4 \mathrm{~V}$ 辺りに 2 個の極大波を有する還元波が あり，ゼラチンでもって抑制すれば曲線 $a^{\prime}$ のように 2 段の還元波を示し，第 1 波の半波電位は $-0.93 \mathrm{~V}$ ，第 2 波のそれは $-1.11 \mathrm{~V}$ であった。

Fig. 1 のグラム b は濃度 $1.0 \times 10^{-3} M$ の T. P. Sul. C. ( $1 \mathrm{~F}$ 塩化ナトリウム支持) について，上と同様にし

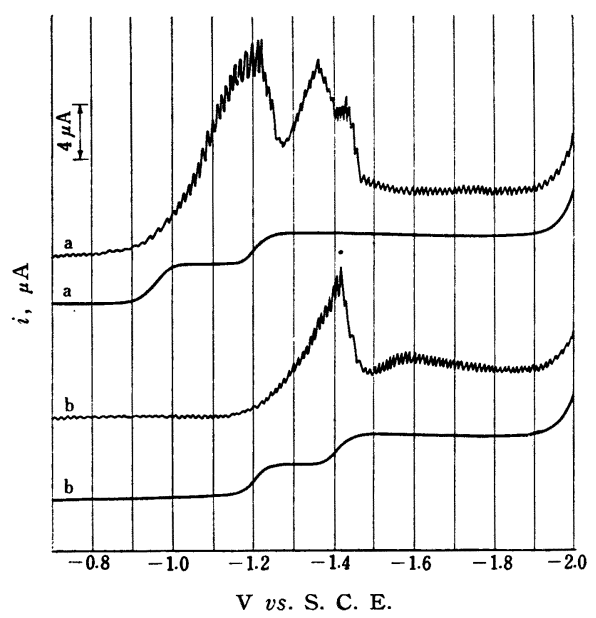

Fig. 1 Polarograms of T. P. Se. C. and T. P. Sul. C.

a: $1.0 \times 10^{-3} M$ T.P.Se. C. in $1 \mathrm{~F} \mathrm{NaCl}$ without suppressor $\mathrm{a}^{\prime}: 1.0 \times 10^{-3} M$ T. P. Se. C. in $1 \mathrm{~F} \mathrm{NaCl}$ with gelatin b : $1.0 \times 10^{-3} M$ T.P. Sul. C. in $1 \mathrm{~F} \mathrm{NaCl}$ without suppressor $b^{\prime}: 1.0 \times 10^{-3} M$ T. P. Sul. C. in $1 \mathrm{~F} \mathrm{NaCl}$ with fuchsin 


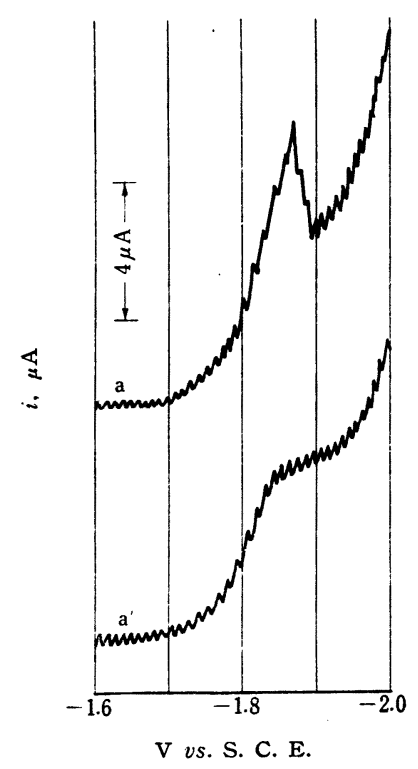

Fig. 2 Polarograms of tetraphenylphosphonium chloride with and without maximum suppressor

a : $1.0 \times 10^{-3} M$ T.P.P.C. in $1 \mathrm{~F} \mathrm{NaCl}$ without suppressor $\mathrm{a}^{\prime}: 1.0 \times 10^{-3} \mathrm{M}$ T. P. P. C. in $1 \mathrm{~F} \mathrm{NaCl}$ with dodecyltrimethyl-ammonium chloride

て得たポーラログラムで， $-1.35 \mathrm{~V}$ 辺りに極大波を伴 う還元波を示すが，塩基性フクシンを添加して得たポー ラログラムは曲線 b' のように 2 段の還元波を与え, 第 1 波の半波電位は $-1.18 \mathrm{~V}$, 第 2 波のそれは $-1.38 \mathrm{~V}$ であった。

Fig. 2 のグラム a は濃度 $1.0 \times 10^{-3} M$ の T. P. P. C. (1F 塩化ナトリウム支持) 溶液について, 上と同様にし て得たポーラログラムで, $-1.85 \mathrm{~V}$ 辺りに極大波を伴う 1 段の還元波を与える. この極大波はドデシルトリメチ ルアンモニウム・クロライドを添加すると，抑制されて 曲線 $a^{\prime}$ のように 1 段の還元波を示す.

さらに濃度と波高との比例性について検討したものが Fig. 3，4 および 5 の各直線 a で T. P. Se. C. では $0.5 \times 10^{-4} \sim 1.0 \times 10^{-2} M$ 間に, T. P. Sul. C. では 1.0 $\times 10^{-4} \sim 5.0 \times 10^{-3} M$ 間に, T. P. P.C. では $5.0 \times 10^{-5}$ $\sim 1.0 \times 10^{-2} M$ 間に直線的関係がみられた。

\section{$2 \cdot 2 \cdot 2$ 電流滴定 オ二ウム濃度 $1.0 \times 10^{-3} M$ の水} 溶液 ( $1 \mathrm{~F}$ 塩化ナトリウム支持) $100 \mathrm{ml}$ に $1.0 \times 10^{-2} M$ のテトラフェニルボロ・ナトリウム溶液を $1 \mathrm{ml}$ ずつ添 加, 脱酸素後銀-塩化銀電極を対極として 滴定曲線を得 た図が Fig. 3，4 および 5 の各曲線bである. T. P. Se. C. の場合は $-1.93 \mathrm{~V}$, T. P. Sul. C. の場合は

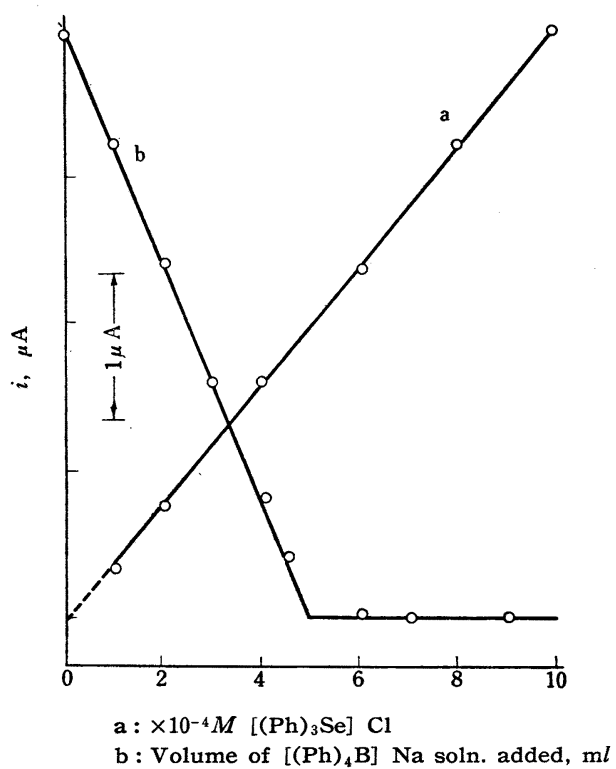

Fig. 3 Titration of $(\mathrm{Ph})_{3} \mathrm{Se} \mathrm{Cl}$ with $(\mathrm{Ph})_{4} \mathrm{~B} \mathrm{Na}$

a : Linear proportionality of wave-heights with the concentrations of T.P.Se. C. (in $1 \mathrm{~F} \mathrm{NaC1)}$

b : Titration curve

$1.0 \times 10^{-3} M(\mathrm{Ph})_{3} \mathrm{Se} \mathrm{Cl}$ in $1 \mathrm{~F} \mathrm{NaCl}: 100 \mathrm{ml}$

$1.0 \times 10^{-2} M(\mathrm{Ph})_{4} \mathrm{~B} \mathrm{Na}$ soln.

Applied potential : $-1.8 \mathrm{~V}$ vs. S. C. E.

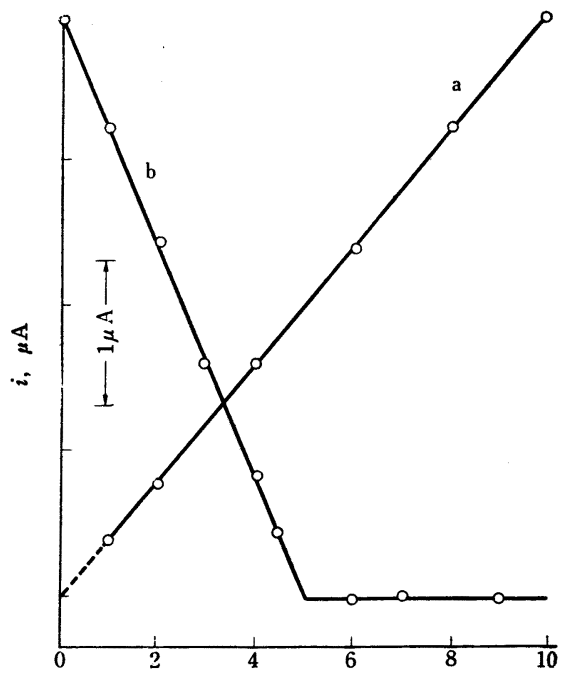

$\mathrm{a}: \times 10^{-4} M\left[(\mathrm{Ph})_{3} \mathrm{~S}\right] \mathrm{Cl}$

$\mathrm{b}$ : Volume of $\left[(\mathrm{Ph})_{4} \mathrm{~B}\right] \mathrm{Na}$ soln. added, $\mathrm{ml}$

Fig. 4 Titration of $(\mathrm{Ph})_{3} \mathrm{~S} \mathrm{Cl}$ with $(\mathrm{Ph})_{4} \mathrm{~B} \mathrm{Na}$

a : Linear proportionality of wave-heights with the concentration of T.P.Sul. C. (in $1 \mathrm{~F} \mathrm{NaCl}$ )

b : Titration curve

$1.0^{-3} M(\mathrm{Ph})_{3} \mathrm{~S} \mathrm{Cl}$ in $1 \mathrm{~F} \mathrm{NaCl}: 100 \mathrm{ml}$

$1.0 \times 10^{-2} M(\mathrm{Ph})_{4} \mathrm{~B} \mathrm{Na}$ soln.

Applied potential : $-1.75 \mathrm{~V}$ vs. S. C. E. 


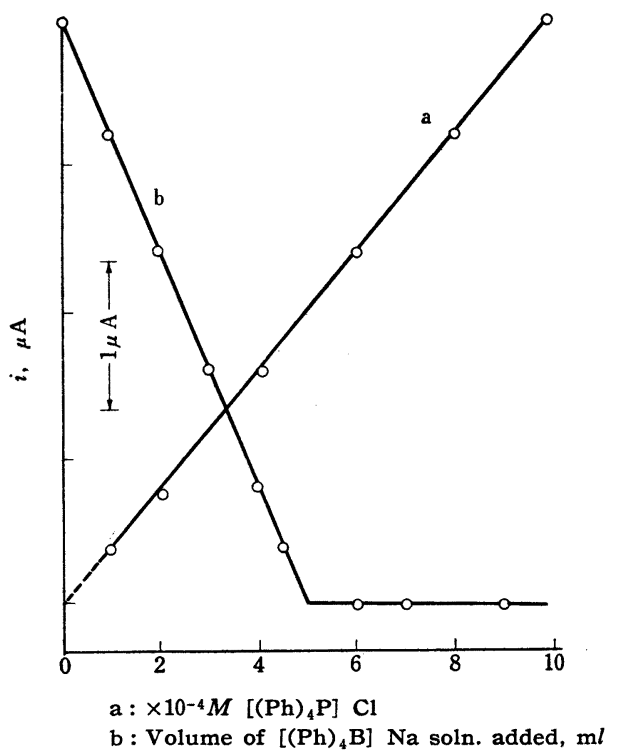

Fig. 5 Titration of $(\mathrm{Ph})_{4} \mathrm{P} \mathrm{Cl}$ with $(\mathrm{Ph})_{4} \mathrm{~B} \mathrm{Na}$

a : Linear proportionality of wave-heights with the concentrations of T.P.P.C. (in $1 \mathrm{~F} \mathrm{NaCl)}$

b : Titration curve

$1.0 \times 10^{-3} M(\mathrm{Ph})_{4} \mathrm{P} \mathrm{Cl}$ in $1 \mathrm{~F} \mathrm{NaCl}: 100 \mathrm{ml}$ $1.0 \times 10^{-2} M(\mathrm{Ph}){ }_{4} \mathrm{~B}$ Na soln.

$-1.8 \mathrm{~V}$ 亿電位を固定し, T.P.P. C. の場合はホスホ ニウム・イオンの還元波の立上りより極大波の落ちてき た点までの高さを測定した。

\section{3 結果の考察}

\section{$3 \cdot 1$ 電流滴定}

水溶液中で負に荷電したテトラフェニルボロニウム． イオンはそれぞれスルホニウム, セレノニウム, ホスホ ニウムの各陽イオンと反応して白色沈殿をつくる.これ らオニウム・イオンによる沈殿現象は陰・陽両イオン間 のポテンシャル積6) (これらの場合 $f \delta<0.20)$ から説明 できないむむしろ，定性的ではあるが，Feigl の唱える weighting effect および size effect》 の考元に従っ て考察すると，その高い沈殿生成能が予想される。これ ら沈殿反応は次のように表わされ, 実験の結果生成沈殿 体の水への溶解度はきわめて小さいと考光られる：

$$
\begin{aligned}
{\left[(\mathrm{Ph})_{3} \mathrm{~S}\right] \mathrm{Cl}+} & {\left.[\mathrm{Ph})_{4} \mathrm{~B}\right] \mathrm{Na} } \\
& \rightleftarrows\left[(\mathrm{Ph})_{3} \mathrm{~S}\right]\left[(\mathrm{Ph})_{4} \mathrm{~B}\right]+\mathrm{NaCl} \\
{\left[(\mathrm{Ph})_{3} \mathrm{Se}\right] \mathrm{Cl}+} & {\left[(\mathrm{Ph})_{4} \mathrm{~B}\right] \mathrm{Na} } \\
& \rightleftarrows\left[(\mathrm{Ph})_{3} \mathrm{Se}\right]\left[(\mathrm{Ph})_{4} \mathrm{~B}\right]+\mathrm{NaCl} \\
{\left[(\mathrm{Ph})_{4} \mathrm{P}\right] \mathrm{Cl}+\left[(\mathrm{Ph})_{4} \mathrm{~B}\right] \mathrm{Na} } & \rightleftarrows\left[(\mathrm{Ph})_{4} \mathrm{P}\right]\left[(\mathrm{Ph})_{4} \mathrm{~B}\right]+\mathrm{NaCl}
\end{aligned}
$$

沈殿反応の結果, 塩化ナトリウムを生ずるので，銀-塩 化銀電極の性格とあわせ考光, 支持電解質としても同じ く塩化ナトリウムをえらび，実験を進めた.

電流滴定の結果 Fig. 3， 4 および 5 の各曲線 b から わかるように，上記諸反応により得られた 沈殿組成は onium $^{+}:(\mathrm{Ph})_{4} \mathrm{~B}^{-}=1: 1$ であることがわかった． 沈 殿 $\left[(\mathrm{Ph})_{4} \mathrm{P}\right]\left[(\mathrm{Ph})_{4} \mathrm{~B}\right]$ については Wittig およびRaff $\left.{ }^{8}\right)$ も $\mathrm{B}, \mathrm{C}_{6} \mathrm{H}_{5}$ の分析により同様の結果を得ている.

これら滴定操作は, いずれも 5 分以内で完了し，定量 はいずれも誤差 $3 \%$ 以内で行なうことができた。この点 重量法に比べ操作時間が短く, さらに沈殿乾燥の問題は なく，迅速簡便に分析を行なうことができる上に，精度 む良好である．ただし試薬溶液は数日放置すると分解す るおそれがあるが，これは滴定に際し新しく調製するこ とにより，その欠点を補うことができる. 試薬添加後の 筧汼は脱酸素をかねて窒素ガスを通気すればよい。

\section{$3 \cdot 1$ 沈殿の溶解度皘9 910 )}

Bを含む溶液を試薬 $\mathrm{A}$ の溶液で滴定した場合次のごと く沈殿 B Aを生ずると仮定する :

$$
\mathrm{B}+\mathrm{A} \rightleftarrows \mathrm{BA}
$$

いま設定電位においてBは還元波を与えるが，Aおよび B A はそれぞれ還元波，酸化波のいずれをも与充ないと する．BA は難溶性であるが，溶液中では完全にAおよ びBに解離し，かつ，溶液中の物質とは錯イオンを形成 しないとする。

滴定溶液中の $\mathrm{A}$ の濃度および $\mathrm{B}$ の濃度の積が $\mathrm{BA}$ の溶 解度積 $\mathrm{S}_{\mathrm{BA}}$ より小さくないかぎり，溶液中では， $\mathrm{B}+$ $\mathrm{A} \rightarrow \mathrm{BA}$ の反応がおこり，溶液中における $\mathrm{A}$ および $\mathrm{B} の$ 濃度 $[\mathrm{A}]$ および $[\mathrm{B}]$ は,

$$
[B][A]=S_{B A}
$$

によって規定される.

いま, $\mathrm{B}$ の初期濃度を $b M$ とし, 添加したAが沈殿 しなかった場合に溶液中でとるべき濃度を $a M$ とす る. 滴定曲線上の任意の点における電流值は次の二式の うちいずれかによって決定される.

$$
\begin{array}{ll}
i=k_{\mathrm{B}} b & \left(a \times b \leqq \mathrm{~S}_{\mathrm{BA}} \text { のとき }\right) \\
i=k_{\mathrm{B}}[\mathrm{B}] & \left(a \times b>\mathrm{S}_{\mathrm{BA}} \text { のとき }\right)
\end{array}
$$

$k_{\mathrm{B}}$ は B の単位濃度に対する電流值 $[\mu \mathrm{A} / M]$ であ る.（4）の場合には，

$$
a-[\mathrm{A}]=b-[\mathrm{B}]
$$

の関倸が成立する. (4) および (5) 式から, 
Table II The solubility product of $\left[\right.$ onium $\left.{ }^{+}\right]\left[(\mathrm{Ph})_{4} \mathrm{~B}^{-}\right]$

(The original concentration of $\left[\right.$ onium $\left.^{-}\right], \mathrm{b}$, is equal to $10^{-3} \mathrm{M}$ )

\begin{tabular}{|c|c|c|c|c|c|c|c|}
\hline \multirow{2}{*}{ Precipitate } & \multirow{2}{*}{$\begin{array}{c}k_{\mathrm{B}} \\
(\mu \mathrm{A} / M)\end{array}$} & \multirow{2}{*}{$\begin{array}{c}i \\
(\mu \mathrm{A})\end{array}$} & \multirow{2}{*}{$\begin{array}{c}a \\
(M)\end{array}$} & \multirow{2}{*}{$\begin{array}{c}x \\
(\%)\end{array}$} & \multirow{2}{*}{$\begin{array}{c}y \\
(\%)\end{array}$} & \multicolumn{2}{|c|}{ Solubility product obtained } \\
\hline & & & & & & from eq. (8) & from eq. (11) \\
\hline$\left[(\mathrm{Ph})_{3} \mathrm{~S}\right]\left[(\mathrm{Ph})_{4} \mathrm{~B}\right]$ & $4.2 \times 10^{3}$ & 1.35 & $4 / 5 \times 10^{-3}$ & $3 / 28 \times 100$ & 20 & $3.9 \times 10^{-8}$ & $3.2 \times 10^{-8}$ \\
\hline$\left[(\mathrm{Ph})_{3} \mathrm{Se}\right]\left[(\mathrm{Ph})_{4} \mathrm{~B}\right]$ & $4.35 \times 10^{3}$ & 1.2 & $4 / 5 \times 10^{-3}$ & $2 / 29 \times 100$ & 20 & $2.1 \times 10^{-8}$ & $1.9 \times 10^{-8}$ \\
\hline$\left[(\mathrm{Ph})_{4} \mathrm{P}\right]\left[(\mathrm{Ph})_{4} \mathrm{~B}\right]$ & $4.3 \times 10^{3}$ & 1.1 & $4 / 5 \times 10^{-3}$ & $2.5 / 43 \times 100$ & 20 & $1.1 \times 10^{-8}$ & $1.4 \times 10^{-8}$ \\
\hline
\end{tabular}

$$
\begin{aligned}
& {[\mathrm{A}]=\frac{i}{k_{\mathrm{B}}}-(b-a)} \\
& {[\mathrm{B}]=\frac{i}{k_{\mathrm{B}}} \quad \cdots \cdots \cdots}
\end{aligned}
$$

の関係がえられる.（6)および (7) 式を(2) 式に代入し， 整理すると,

$$
\left(k_{\mathrm{B}}\right)^{2} \mathrm{~S}_{\mathrm{BA}}+k_{\mathrm{B}}(b-a) i-i^{2}=0 \quad\left(a \times b>\mathrm{S}_{\mathrm{BA}} \text { のとき }\right)
$$

（3）および (8) 式で滴定曲線の全範囲を表わしている. $i, k_{\mathrm{B}}, a$ および $b$ は実験から求められるので $\mathrm{S}_{\mathrm{BA}}$ がど のくらいの大きさか推察できる.

別法として, 共通イオン効果により沈殿体の溶解度が 定量的に抑制されている場合， 2 直線が当量点で交わる ことを利用した Kolthoff および Lingane ${ }^{10)}$ の方法が ある.この方法では所定電位で $\mathrm{B}+$ のみが還元する沈殿 BA について, 当量点前 $x \%$ で溶解度が $\mathrm{B}$ の初期濃 度の $y \%$ である場合, 良好な滴定結果が得られると仮 定する.

$\mathrm{B}^{+}$の初期濃度を $b$ とし, 当量点前 $y \%$ で $\mathrm{B}^{+}$が A-で滴定されるとすれば :

$$
\begin{aligned}
& {\left[\mathrm{A}^{-}\right]=\frac{x b}{100}} \\
& {\left[\mathrm{~B}^{+}\right]=\frac{y b}{100}+\frac{x b}{100}} \\
& {\left[\mathrm{~B}^{+}\right]\left[\mathrm{A}^{-}\right]=\mathrm{S}_{\mathrm{BA}}=\frac{x y b^{2}}{10^{4}}+\left(\frac{x b}{100}\right)^{2}}
\end{aligned}
$$

Table II は滴定結果をとれぞれ (8) および (11) 式 に適用して求めた溶解度積の概算值である.これらの值 は大体 $10^{-8}$ の範囲で $\left[\left(\mathrm{CH}_{3}\right)_{4} \mathrm{~N}\right]\left[(\mathrm{Ph})_{4} \mathrm{~B}\right]$ について 報告されている值 ${ }^{11)} 1.4 \times 10^{-6}$ に比較すると 2 桁ほど 小さく, 沈殿生成能が $\mathrm{C}_{6} \mathrm{H}_{5}$ 基をもつことにより高くな ってきたことを示す.

終りに臨み本研究を終始御指導下さった品川睦明教授 ならびに松尾 博助教授に深く感謝致します。な打本研 究は品川教授に対する文部省科学研究費の補助により行 なったるのであり，ててに記して感謝する.

(昭和 30 年 11 月 21 日, ポーラログラフ討論会講演)

\section{交献}

1) 品川睦明, 松尾 博 : 化学の領域, 10, 111 (1956).

2) P. H. Heemans : "Introduction to Theoretical Organic Chemistry”, p. 67 (1954), (Elsevier Publishing Company, New York).

3) 品川睦明, 松尾 博, 真木伸文 : 本誌, 5, 80 (1956).

4) 品川睦明, 松尾 博, 一色節也 : 同上, 3, 199 (1954).

5）品川睦明, 松尾 博, 根津弘幸 : 同上， 5, 20 (1956).

6) 檤田竜太郎 : 同上, 4, 127 (1955).

7) F. Feig1 : "Chemistry of Specific, Selective and Sensitive Reactions”, p. 411 (1949), (Academic Press, Inc., New York).

8) G. Wittig, P. Raff : Ann., 573, 195 (1951).

9）日本化学会編：“実験化学講座 15 分析化学 (上)”, p. 433 (1957), (丸善).

10) I. M. Kolthoff, J. J. Lingane : "Polarography”, 2nd Ed., Vol. II, p. 896 (1952), (Interscience Publishers Inc., New York).

11) L. Zeidler : Hoppe-Seyler's Z. physiol. Chem., 291, 177 (1952).

$$
\text { is }
$$

Amperometric titrations of several onium compounds with sodium tetraphenylborate. (Studies on the analytical application of onium compounds. XX.) Hiroyuki NezU (Dept. of Chem., Faculty of Science, Univ. of Hiroshima)

The investigation dealed with the application of sodium tetraphenylborate as a quantitative reagent for triphenylsulfonium, triphenylselenonium, and tetraphenylphosphonium salts by amperometric titration. As a reference electrode, silversilver chloride was used. The titrations of triphenylsulfonium salt $\left(10^{-3} M\right)$, triphenylselenonium salt $\left(10^{-3} M\right)$ and tetraphenylphosphonium salt $\left(10^{-3} M\right)$ were carried out within an error of $\pm 3 \%$, respectively. The reactions of precipitation were formulated as:

(1) $\mathrm{Ph}_{3} \mathrm{SCl}+\mathrm{Ph}_{4} \mathrm{BNa}=\mathrm{Ph}_{3} \mathrm{SPh}_{4} \mathrm{~B}+\mathrm{NaCl}$

(2) $\mathrm{Ph}_{3} \mathrm{SeCl}+\mathrm{Ph}_{4} \mathrm{BNa}=\mathrm{Ph}_{3} \mathrm{SePh}_{4} \mathrm{~B}+\mathrm{NaCl}$

(3) $\mathrm{Ph}_{4} \mathrm{PCl}+\mathrm{Ph}_{4} \mathrm{BNa}=\mathrm{Ph}_{4} \mathrm{PPh}_{4} \mathrm{~B}+\mathrm{NaCl}$

The solubility products of these precipitates were estimated from the polarographic data, and were in the same order of $10^{-8}$.

(Received Nov. 17, 1960) 